\title{
Editorial
}

\section{Rever o passado olhando o futuro}

\section{Looking forward without losing track of the past}

\author{
Jaime Portugal, Duarte Marques
}

Editores-chefe

Nos últimos anos, temos assistido à transformação das linhas orientadoras de edição da Revista Portuguesa de Estomatologia, Medicina Dentária e Cirurgia Maxilofacial. Tal mudança reflete a estratégia assumida pelas últimas direções da Sociedade Portuguesa de Estomatologia e Medicina Dentária (SPEMD) e as alterações que a Medicina Dentária e a Estomatologia sofreram na última década.

Os diversos esforços que a SPEMD tem realizado no apoio à criação e divulgação de ciência, dentro e fora de Portugal, permitiram que a Revista passasse a assumir-se como um veículo de divulgação de trabalhos de investigação original. Os artigos de revisão narrativa e casos clínicos representavam a esmagadora maioria do material publicado. Em 2010, por exemplo, os artigos de investigação não correspondiam sequer a $25 \%$ dos artigos publicados. Desde então, o volume de artigos de investigação original tem vindo a subir de forma gradual e sustentada, atingindo, no ano passado, $84 \%$ do total de artigos que a Revista publicou.

Por outro lado, a Revista tem apostado na sua internacionalização. Atualmente, além de apresentar um Conselho Editorial constituído por investigadores e clínicos de renome internacional, a Revista é distribuída por bibliotecas de diversas Faculdades de Medicina Dentária dos países de língua oficial portuguesa e é publicada em regime de Open Access. A Revista está também indexada em diversas bases internacionais e é pesquisável e acessível através de diversos motores de busca como a Scopus, SCimago, Google Académico e Índex de Revista Médicas Portuguesas. Tal exposição internacional e o incentivo à publicação de artigos escritos em inglês tem permitido que a Revista seja escolhida por autores oriundos de diversos países para a submissão dos seus trabalhos e que o número de citações pela comunidade internacional tenha vindo a aumentar.

É de crer que o aumento do número e da qualidade dos trabalhos submetidos permita manter, ou até mesmo aumentar, o nível já atingido. Tal parece ser também a opinião da Thompson Reuters pois, no final de 2016, a Revista passou a fazer parte da coleção da prestigiada Web of Science através da sua indexação no Emerging Sources Citation Index.

No seguimento da política de rigor e independência que sempre norteou a Revista, este ano, a SPEMD passa a assumir a total responsabilidade pela sua edição, deixando de contar com a assessoria da Elsevier e passando a ter a colaboração da Ciência e Vida. Apesar de algumas alterações gráficas, todo o processo de submissão eletrónica dos trabalhos continua a ser realizado pela plataforma Editorial Manager, utilizada por diversos jornais científicos de renome e que tem permitido assegurar a gestão dos artigos de uma forma isenta, eficaz e rigorosa. 